\title{
PENERAPAN METODE DRILL TERHADAP PENINGKATAN KEMAMPUAN MENULIS AKSARA ULU
}

\author{
Nur Nisai Muslihah ${ }^{1,}$ Yeni Asmara ${ }^{2}$ \\ STKIP-PGRI Lubuklinggau ${ }^{1,2}$ \\ nurnisai@yahoo.co.id ${ }^{1}$
}

Submit, 09-04-2019 Accepted, 23-06-2019 Publish, 23-06-2019

\begin{abstract}
ABSTRAK
Penelitian ini bertujuan untuk mendeskrispsikan penerapan Metode Drill dalam meningkatkan kemampuan menulis Aksara Ulu mahasiswa Program Studi Pendidikan Bahasa dan Sastra Indonesia STKIP-PGRI Lubuklinggau. Metode yang digunakan dalam penelitian ini adalah metode deskriptif kuantitatif dengan jenis penelitian eksperimen semu (Quasi Eksperimen). Populasi dalam penelitian ini adalah seluruh mahasiswa semester III Program Studi Pendidikan Bahasa dan Sastra Indonesia kelas A dan B sebanyak 53 orang dengan sampelnya adalah kelas B yang berjumlah 26 orang. Pengumpulan data dengan menggunakan tes berbentuk essai. Adapun teknik analisis datanya menggunakan uji-t. Dari hasil analisis data diperoleh nilai rata-rata mahasiswa dalam menulis Aksara Ulu setelah menggunakan metode Drill $(84,92)$ lebih besar jika dibandingkan dengan sebelum menggunakan metode Drill $(59,85)$ dan mengalami peningkatan sebesar 25,07. Hasil uji hipotesis menunjukkan bahwa pada taraf signifikansi $5 \%$ nilai $t_{0}>t_{t}, 11,61>2,78$ dan 11,61 $>2,06$. Simpulan, penerapan metode Drill secara signifikan dapat meningkatkan kemampuan menulis aksara Ulu
\end{abstract}

Kata Kunci: Metode Drill, Menulis, Aksara Ulu

\section{ABSTRACT}

This research aims to improve the application of Drill method in enhancing the writing ability of Ulu Script student of Bahasa Indonesia language and literature Education Program STKIP-PGRI Lubuklinggau. The method used in this research is a quantitative descriptive method with the research type of pseudo experiments (quasi experiment). The population in this study is all students of the third semester of the Indonesian Language and Literature Education study Program A and B class of 53 with the sampling is class $B$ that amounted to 26 people. Data collection using an essai-shaped test. The data analysis technique uses $t$-test. From the results of the study obtained the average value of students after using the Drill method (84.92) is greater than before using the Drill (59.85) method and increased by 25,07. The hypothesis test results showed that at a rate of significance $5 \%$ value $t_{\text {hit }}>t_{\text {tab }}, 11,61>2.78$ and $11.61>2.06$. Conclusion, this means that the application of Drill method can significantly improve the writing ability of the students of Ulu Script

Keywords: Drill Methode, Writing, Ulu Script 


\section{PENDAHULUAN}

Salah satu bagian dari kebudayaan yang ada di Indonesia adalah bahasa yang digunakan untuk berkomunikasi dalam masyarakat sesuai dengan daerahnya masingmasing, seperti penggunaan aksara daerah. Aksara daerah merupakan aksara-aksara yang ada di wilayah setiap daerah di Indonesia. Menurut Kozok (dalam Collins, 2010) hampir semua aksara daerah yang ada di Indonesia merupakan turunan Aksara Pallawa dari India Selatan. Aksara Jawi, Aksara Pegon, dan Aksara Bilang-bilang merupakan turunan Abjad Arab, sedangkan Aksara Nagari berasal dari daerah India Utara. Aksara Pallawa dan Aksara Nagari adalah turunan dari Aksara Brahmi yang merupakan induk dari semua aksara di Asia Selatan dan Asia Tenggara.

Beberapa aksara daerah dinamai menurut susunan huruf-hurufnya atau menurut nama abecedarium aksara tersebut. Aksara Jawa Baru dan Aksara Bali disebut Aksara Hanacaraka; sedangkan Aksara Rejang, Aksara Kerinci, Aksara Lampung, dan Aksara Sunda Baku disebut juga Aksara Ka ga nga mengikuti abecedarium Aksara Pallawa: ka kha ga gha nga. Mengenai kondisi aksara daerah di Indonesia saat ini, menurut Rosidi, ada sejumlah bahasa daerah yang memiliki aksara sendiri sehingga memiliki tradisi tulisan yang cukup lama, antara lain: bahasa Jawa, bahasa Bugis, dan bahasa Batak. Sedangkan mengenai kondisi Bahasa, Muatan lokal, dan Aksara daerah yang lainnya saat ini dalam http:pusat bahasa.depdiknas.go.id.diakses pada 01 April 2018, pukul 21: 09 WIB. dikemukakan hasil wawancara Abdul Wahab dengan mahasiswa program S2 dan S3 sebagai penutur asli bahasa Bali, Jawa, Bugis, Makasar, Bima, Lampung, dan Batak mempunyai aksara daerah sendiri meskipun kini hanya sebagian generasi yang berusia 40 tahun ke atas saja yang mampu mengenali aksara daerah. Itu pun terbatas pada tingkatan recognitif, bukan pada tingkatan produktif. Pada kalangan generasi usia 20 tahun ke bawah, aksara daerah itu mereka anggap sebagai hiasan museum belaka.

Aksara daerah yang dimiliki dan digunakan oleh masyarakat Kota Lubuklinggau pada zaman dahulu adalah Aksara Ulu yang disebut dengan Aksara Ulu

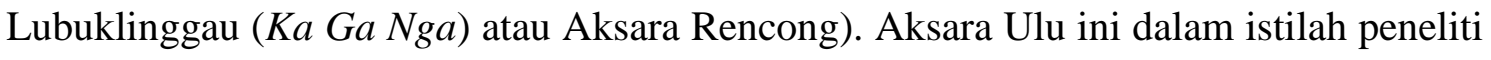
asing disebut aksara $\mathrm{Ka}$ Ga Nga karena pedoman aksaranya mempergunakan $\mathrm{Ka} G a$ Nga. Aksara Ulu ini dikenal dan dikembangkan oleh masyarakat Sumatra bagian selatan (Pesisir) yaitu etnis Pasemah, Serawai, Rejang, dan Lembak. Aksara Ulu terdiri dari 
banyak jenis diantaranya Aksara Ulu Serawai, Aksara Ulu Pasemah, Aksara Ulu Rejang, Aksara Ulu Lembak, Aksara Ulu Palembang, dan Aksara Ulu Lampung (Sarwono, S. dalam Miranda, 2014:5).

Aksara ulu ini merupakan salah satu khazanah kebudayaan bangsa Indonesia telah berkembang pada abad ke 17-19 Masehi yang dipergunakan sebagai alat rekam sistem bunyi bahasa suatu bangsa untuk mengekspresikan diri. Tulisan tersebut biasanya digunakan untuk menyampaikan ajaran agama, pengobatan, petuah dan kearifan lokal lain. Menurut Dewi (2017) dan Syam (2015) Aksara ulu Lubuklinggau memiliki 19 huruf tunggal dan 8 huruf pasangan, huruf-huruf ditulis dengan cara ditarik ke kanan atas sampai sekitar 45 derajat.

Ironisnya, keberadaan Aksara Ulu Lubuklinggau kurang dikenal oleh generasi masa kini. Hanya para orang tua maupun tetua adat yang mengetahui bahkan hampir hanya menjadi dokumen yang tersimpan di rumah dan tidak digunakan sebagai sarana untuk berkomunikasi. Kondisi ini sangat memprihatinkan. Bila hal ini dibiarkan maka Aksara Ulu di Kota Lubuklinggau ini akan mengalami kepunahan. Sebagaimana disampaikan oleh Rusmana Dewi seorang budayawan Kota Lubuklinggau bahwa upaya pelestarian Aksara Ulu di Kota Lubuklingau masih terkendala diantaranya adalah sebagian besar masyarakat belum mengerti dan paham dengan Aksara Ulu tersebut (Linggau Pos Online 3 Desember 2017 dengan judul pelestarian Aksara Ulu banyak kendala). Padahal aksara daerah (Aksara Ulu) merupakan aset dan kekayaan yang dimiliki oleh daerah Lubuklinggau.

Menyikapi berbagai kondisi di atas, perlu adanya suatu sistem yang mampu mensinergikan budaya daerah termasuk Aksara Ulu Lubuklinggau agar tetap dilestarikan oleh generasi muda sehingga Aksara Ulu tidak menjadi butir sejarah saja. Oleh karena itu, sudah sewajarnya jika pada Program Studi Pendidikan Bahasa dan Sastra Indonesia STKIP-PGRI Lubuklinggau dimasukkan Mata Kuliah Bahasa dan Sastra Daerah. Salah satu materi dalam capaian pembelajaran pada mata kuliah ini adalah mahasiswa dapat menulis dengan menggunakan Aksara Ulu Lubuklinggau.

Menulis merupakan suatu keterampilan yang dibutuhkan dalam pembelajaran, dan menulis merupakan keterampilan berbahasa yang tingkat kesulitannya paling tinggi. Terkait hal ini Tarigan (2008) menjelaskan bahwa menulis merupakan suatu keterampilan berbahasa yang dipergunakan untuk berkomunikasi secara tidak langsung, 
tidak secara tatap muka dengan orang lain. Dalam keterampilan ini, penulis harus terampil memanfaatkan grafologi, struktur bahasa, dan kosakata. Selain itu, keterampilan menulis tidak datang secara otomatis, tetapi harus melalui latihan dan praktik yang banyak dan teratur. Hal Ini mengisyaratkan bahwa semakin sering mahasiswa berlatih dalam menulis Aksara Ulu maka mahasiswa tersebut semakin terampil karena menulis merupakan salah satu dari keterampilan berbahasa.

Berdasarkan hasil pembelajaran menulis Aksara Ulu dalam tiga tahun terakhir ini diketahui bahwa mahasiswa mengalami kesulitan dalam menulis huruf ulu sesuai dengan ketentuan. Selain itu mahasiswa keliru meletakkan penanda baca dalam huruf Ka Ga Nga. Padahal menulis merupakan sarana komunikasi non verbal untuk menyampaikan pesan secara tidak langsung, Namun untuk dapat menulis dengan menggunakan Aksara Ulu bukanlah suatu hal yang mudah, karena membutuhkan suatu keterampilan dan ketelitian yang mencakup kerapian, bentuk huruf, bentuk tulisan, penggunaan penanda baca, dan peletakan penanda baca. Mengingat bahwa keterampilan menulis ini tidak datang secara otomatis namun melalui tahap latihan dan praktik yang banyak dan teratur, maka dalam pembelajaran menulis Aksara Ulu ini diperlukan metode pembelajaran yang efektif dan efesien sehingga tujuan pembelajaran dapat tercapai secara optimal.

Menurut Murniadih (2017); Irwanti (2017) dengan pengembangan model bahan ajar dapat meningkatkan kemampuan menulis berita dan puisi, begitu jug hasil penelitian Indriaty (2018), melalui metode pembelajaran quantum learning dapat meningkatkan kemampuan menulis berita. Sedangkan menurut Juita (2018) model pembelajaran berbasis portofolio dapat meningkatkan kemampuan menulis laporan. Hasil penelitian Lazuardi dan Murti (2018) model pembelajaran quantum tipe VAK dapat meningkatkan kemampuan menulis puisi. Kemudian Muhtadin (2017) model pembelajaran Cooperative Integrated Reading and Composition (CIRC) dapat meningkatkan kemampuan menulis proposal. Menurut Sari (2017) terdapat hubungan antara pengetahuan kebahasaa dengan kemampuan menulis, menurut Noermanzah, Abid, dan Aprika (2008), menjelaskan model pembelajaran teknik send a problem dapat meningkatkan kemampuan menulis daftar pustaka 
Dengan demikian pengembangan bahan ajar dan penggunaan model pembelajaran dapat meningkatkan kemampuan menulis pusi, berita dan laporan, maka dalam penelitian ini penelitian menggunakan metode drill dalam meningkatkan kemampuan menulis aksara ulu, sebab metode drill salah satu metode pembelajaran yang melibatkan peran serta mahasiswa untuk berlatih secara berulang-ulang adalah metode Drill.

Menurut Sagala (2003) metode drill adalah suatu metode mengajar yang baik untuk menanamkan kebiasaan-kebiasaan tertentu, selain itu sebagai sarana untuk memperoleh suatu ketangkasan, ketepatan, kesempatan dan keterampilan. Metode latihan biasanya digunakan dengan tujuan agar siswa/mahasiswa memiliki keterampilan motoris atau gerak: seperti meghafalkan kata-kata, menulis, mempergunakan alat/suatu benda. Lebih lanjut Djamarah (2010) mengemukakan bahwa metode Drill merupakan metode dimana guru/dosen memberikan pelatihan keterampilan secara berulang kepada mahasiswa dan mengajaknya langsung ke tempat keterampilan untuk melihat proses, tujuan, fungsi, kegunaan dan manfaat sesuatu. Tujuan penerapan metode Drill ini adalah membentuk kebiasaan atau pola yang otomatis pada peserta didik.

\section{METODE PENELITIAN}

Metode penelitian yang digunakan dalam penelitian ini adalah metode deskriptif kuantitatif dengan jenis penelitian eksperimen semu (Quasi Eksperimental). Menurut Syamsudin dan Damayanti (2011) Quasi eksperimental design digunakan karena pada kenyataannya sulit mendapatkan kelompok kontrol yang digunakan dalam penelitian. Menurut Arikunto (2010) "pretest and post test group design adalah observasi yang dilakukan sebanyak dua kali yaitu sebelum eksperimen (pretest) dan sesudah eksperimen (posttest) dengan satu kelompok subjek." Dalam penelitian ini tes diberikan sebanyak dua kali yaitu tes awal (pretest) untuk mengetahui sejauh mana kemampuan yang dimiliki mahasiswa dalam menulis aksara Ulu. Setelah diberikan tes awal, penulis melakukan eksperimen dengan memberikan perlakuan berupa pembelajaran Aksara Ulu dengan menggunakan metode Drill. Tindakan akhir yang dilakukan penulis adalah dengan mengadakan tes akhir (post test) tujuannya untuk mendapatkan perbandingan data tes awal (pretest) dan tes akhir (postest). Berikut rancangan the pretest-posttest group design: 


$$
\mathrm{O}_{1} \quad \mathrm{X} \quad \mathrm{O}_{2}
$$

$\mathrm{O} 1=$ Nilai pretest (sebelum diberi perlakuan)

$\mathrm{X}=$ Perlakuan (Treatment)

$\mathrm{O} 2$ = Nilai post-test (setelah diberi perlakuan)

Paradigma desain penelitian ini terdapat pretest sebelum diberi perlakuan sehingga hasil perlakuan dapat diketahui lebih akurat, karena dapat membandingkan dengan keadaan sebelum diberi perlakuan. Populasi dalam penelitian ini adalah mahasiswa Program Studi Pendidikan Bahasa dan Sastra Indonesia semester III yang berjumlah 53 orang dan tersebar dalam dua kelas yaitu kelas A dan kelas B. Pengambilan sampel dalam penelitian ini menggunakan teknik simple random sampling. Melalui teknik simple random sampling ini kelas B terpilih sebagai kelas eksperimen.

Instrument penelitian yang digunakan dalam penelitian ini adalah dalam bentuk tes. Tes yang dilakukan berupa tes essai menulis aksara Ulu baik pada saat pre tes maupun pos tes dengan indikator penilaian sebagai berikut: 1) kerapian, 2) bentuk huruf, 3) tulisan, 4) penggunaan penanda baca, dan 5) letak penanda baca.

Tabel 1

Indikator Penilaian Menulis Aksara Ulu

\begin{tabular}{|c|c|c|c|c|c|c|c|}
\hline \multirow[t]{2}{*}{ No } & \multirow[t]{2}{*}{ Aspek yang Dinilai } & \multicolumn{5}{|c|}{ Skor } & \multirow[t]{2}{*}{ Jumlah } \\
\hline & & 1 & 2 & 3 & 4 & 5 & \\
\hline 1 & Kerapian & & & & & & 5 \\
\hline 2 & Bentuk Huruf & & & & & & 5 \\
\hline 3 & Tulisan & & & & & & 5 \\
\hline 4 & Penggunaan Tanda Baca & & & & & & 5 \\
\hline 5 & Letak Penanda Baca & & & & & & 5 \\
\hline & Jumlah & & & & & & 25 \\
\hline
\end{tabular}

Nilai akhir masing-masing mahasiswa diperoleh dari perhitungan dengan rumus berikut:

$$
N A=\frac{\text { SkorPerolehan }}{\text { SkorMaksimal (25) }} \times 100
$$

Untuk mengetahui tingkat kemampuan mahasiswa dalam menulis aksara ulu peneliti berpedoman pada pedoman Akademik STKIP-PGRI Lubuklinggau tahun 2015 
mengenai Perubahan nilai mutlak $0-100$ dalam sistem lambang nilai dan bobot sebagai berikut.

Tabel 2

Konversi Nilai Perubahan Nilai Mutlak 0 - 100

\begin{tabular}{cccc}
\hline Nilai Mutlak & Lambang Nilai & Bobot & ?redikat/Sebutan \\
\hline $8,00-10,00$ & A & 4 & Sangat Baik \\
$6,60-7,99$ & B & 3 & B a i k \\
$5,60-6,59$ & C & 2 & C u k u p \\
$4,60-5,59$ & D & 1 & Kurang \\
$<4,59$ & E & 0 & Gagal.
\end{tabular}

(Pedoman Akademik STKIP-PGRI Lubuklinggau, 2015)

Teknik Analisis Data diawali dengan Uji Normalitas Data dilanjutkan dengan Uji Hipotesis menggunakan Uji-t.

\section{HASIL PENELITIAN}

Data dalam penelitian ini berupa data pretes dan postes yang digunakan untuk mengetahui kemampuan menulis mahasiswa pada materi Aksara Ulu. Data pretes digunakan untuk melihat kemampuan awal mahasiswa menulis Aksara Ulu sebelum diterapkannya metode Drill dan data postes digunakan untuk mengetahui kemampuan menulis mahasiswa setelah diterapkannya metode Drill. Dari hasil analisis data pretest diketahui nilai terendah yang diperoleh mahasiswa adalah 32 dan nilai tertinggi yang diperoleh mahasiswa adalah 76 sedangkan nilai rata-ratanya adalah 59,85 sehingga kemampuan mahasiswa semester III dalam menulis dengan menggunakan Aksara Ulu sebelum diberi pembelajaran dengan menggunakan metode Drill masih dalam kategori gagal. Untuk lebih jelasnya mengenai hasil pre test dapat dilihat pada tabel 3 berikut ini:

Tabel 3

Hasil Tes Awal (Pretes) Kemampuan Menulis Aksara Ulu

\begin{tabular}{lcrcc}
\hline Nomor & & F & $\%$ & Kategori \\
& Rentang Nilai & \multicolumn{1}{c}{$\%$} & \\
\hline 1. & $8,00-10,00$ & 0 & $50,00 \%$ & Sangat Baik \\
2. & $6,60-7,99$ & 10 & $38,46 \%$ & B a i k \\
3. & $5,60-6,59$ & 7 & $26,92 \%$ & C u k u p \\
4. & $4,60-5,59$ & 4 & $15,38 \%$ & Kurang \\
5. & $<4,59$ & 5 & $19,24 \%$ & Gagal. \\
\hline & Jumlah & 26 & $00,00 \%$ & \\
\hline
\end{tabular}


Berdasarkan tabel 3 di atas, maka dideskripsikan bahwa kemampuan mahasiswa Program Studi Pendidikan Bahasa dan Sastra Indonesia dalam menulis aksara Ulu dalam rentangan nilai $8,00-10,00$ sebanyak 0 orang $(00,00 \%)$ sangat baik, yang mendapat nilai dalam rentang 6,60 - 7,99 sebanyak 10 orang $(38,46 \%)$, dalam rentangan 56 - 6,59 sebanyak 7 orang (26,92\%) dengan kriteria cukup, yang mendapat nilai dalam rentang 4,60 - 5,59 sebanyak 4 orang $(15,38 \%)$ dengan kategori kurang, dan yang mendapat nilai 46 - 5,59 sebanyak 5 orang $(19,24 \%)$ dengan kategori gagal.

Kemudian berdasarkan hasil analisis data tes akhir (Postes) diketahui bahwa nilai terendah yang diperoleh mahasiswa adalah 68 dan nilai tertinggi yang diperoleh mahasiswa adalah 96, sedangkan nilai rata-ratanya adalah 84,92. Untuk lebih jelasnya dapat dilihat pada tabel 4 berikut ini

Tabel 4

Hasil Tes Akhir (Postes) Kemampuan Menulis Aksara Ulu

\begin{tabular}{cccc}
\hline Rentang Nilai & F & $\%$ & Predikat/Kategori \\
\hline $8,00-10,00$ & 20 & $76,93 \%$ & Sangat Baik \\
$6,60-7,99$ & 6 & $23,07 \%$ & B a i k \\
$5,60-6,59$ & 0 & $50.00 \%$ & C u k u p \\
$4,60-5,59$ & 0 & $50,00 \%$ & Kurang \\
$<4,59$ & 0 & $50,00 \%$ & Gagal. \\
\hline Jumlah & 26 & $100 \%$ & \\
\hline
\end{tabular}

Berdasarkan tabel 4 di atas, maka dideskripsikan bahwa kemampuan mahasiswa Program Studi Pendidikan Bahasa dan Sastra Indonesia dalam menulis aksara Ulu dalam rentangan nilai 8,00 - 10,00 sebanyak 20 orang $(76,93 \%)$ dengan kategori sangat baik, yang mendapat nilai dalam rentang 6,60-7,99 sebanyak 6 orang $(23,07 \%)$, dalam rentangan 56 - 6,59 sebanyak 0 orang $(00,00 \%)$ dengan kriteria cukup, yang mendapat nilai dalam rentang 4,60 - 5,59 sebanyak 0 orang $(00,00 \%)$ dengan kategori kurang, dan yang mendapat nilai 46 - 5,59 sebanyak 0 orang $(00,00 \%)$ dengan kategori gagal.

Berdasarkan hasil tes awal (Pretes) dan data tes akhir (Postes) diketahui bahwa kemampuan mahasiswa semester III Program Studi Pendidikan Bahasa dan Sastra Indonesia STKIP-PGRI Lubuklinggau dalam menulis aksara Ulu mengalami 
peningkatan dari pretes ke postes. Untuk lebih jelasnya dapat dilihat pada tabel 5 berikut ini.

Tabel 5

Peningkatan Kemampuan Menulis Aksara Ulu

\begin{tabular}{ccccccc}
\hline \multirow{2}{*}{ Nomor } & \multirow{2}{*}{ Rentang Nilai } & \multirow{2}{*}{ Kategori } & \multicolumn{3}{c}{ Pretes } & \multicolumn{2}{c}{ Postes } \\
\cline { 4 - 7 } & & & F & \% & F & \% \\
\hline 1. & $8,00-10,00$ & angat Baik & 0 & $0,00 \%$ & 20 & $76,93 \%$ \\
2. & $6,60-7,99$ & B a i k & 10 & $8,46 \%$ & 6 & $23,07 \%$ \\
3. & $5,60-6,59$ & C u k u p & 7 & $6,92 \%$ & 0 & $00,00 \%$ \\
4. & $4,60-5,59$ & Kurang & 4 & $5,38 \%$ & 0 & $00,00 \%$ \\
5. & $<4,59$ & Gagal. & 5 & $9,24 \%$ & 0 & $00,00 \%$ \\
\hline \multicolumn{2}{c}{ Jumlah } & $\mathbf{2 6}$ & $\mathbf{1 0 0 \%}$ & $\mathbf{2 6}$ & $\mathbf{1 0 0 \%}$ \\
\hline
\end{tabular}

Berdasarkan tabel di atas, maka dideskripsikan terdapat peningkatan kemampuan mahasiswa Program Studi Pendidikan Bahasa dan Sastra Indonesia dalam menulis aksara Ulu dari pretes ke postes. Pada saat pretes mahasiswa yang kemampuannya berada pada rentangan nilai 8,00 - 10,00 dengan kategori sangat baik sebanyak 0 orang $(00,00 \%)$, sedangkan pada saat postes sebanyak sebanyak 20 orang (76,93\%); pada saat pretes mahasiswa kemampuannya berada pada rentangan nilai 6,60 - 7,99 sebanyak 10 orang (38,46\%), sedangkan pada saat sebanyak sebanyak 6 orang $(23,07 \%)$; pada saat pretes kemampuan mahasiswa yang berada dalam rentangan 56 6,59 sebanyak 7 orang $(26,92 \%)$, sedangkan hasil postes 0 orang $(15,38 \%)$; hasil pretes mahasiswa yang mendapat nilai dalam rentang 4,60 - 5,59 sebanyak 4 orang $(15,38 \%)$ dengan kategori kurang, sedangkan pada saat postes sebanyak 0 orang $(00,00 \%)$; dan pada saat pretes mahasiswa yang kemampuannya berada dalam rentangan < 4,59 sebanyak 5 orang $(19,24 \%)$ dengan kategori gagal, sedangkan pada saat postes sebanyak 0 orang $(00,00 \%)$.

Berdasarkan perbedaan kemampuan mahasiswa semester Program Studi Pendidikan Bahasa dan Sastra Indonesia dalam menulis aksara Ulu diketahui adanya peningkatan dari pretes ke postes atau sebelum pembelajaran dan setelah pembelajaran dengan metode Drill, sehingga kemampuan mahasiswa dalam menulis aksara Ulu sebelum pembelajaran dengan metode Drill sebesar 59,85 dan setelah pelaksanaan pembelajaran dengan metode Drill sebesar 84,92. Besarnya peningkatan nilai rata-rata mahasiswa adalah 25,07 $(84,92-59,85=25,07)$. 
Untuk mengetahui peningkatan kemampuan menulis aksara Ulu mahasiswa semester III Program Studi Pendidikan Bahasa dan Sastra Indonesia STKIP-PGRI Lubuklinggau setelah pembelajaran dengan metode Drill diawali dengan menghitung simpangan baku dengan rumus sebagai berikut:

$$
\begin{aligned}
& \bar{X}=\frac{\sum X_{i}}{n} \\
& S=\frac{\sqrt{\sum(X i-\bar{X})^{2}}}{n-1}
\end{aligned}
$$

(Sudjana. 2002)

Keterangan :

$\overline{\mathrm{X}}=$ Skor rata-rata

$\sum \mathrm{Xi}=$ Jumlah semua nilai mahasiswa

$\mathrm{n}=$ Banyak data

$\mathrm{S}$ =Simpangan baku

Berdasarkan penghitungan yang telah dilakukan didapatkan nilai rata-rata dan simpangan baku, baik pada kegiatan pretes dan postes adalah seperti di bawah ini:

Tabel 6

Hasil Penghitungan Rata-rata dan Simpangan Baku

\begin{tabular}{lcc}
\hline Variabel & Rata-rata $(\bar{x})$ & Simpangan baku \\
\hline Pretes & 59,85 & 16,63 \\
\hline Postes & 84,92 & 7,29 \\
\hline
\end{tabular}

Selanjutnya dilakukan perhitungan Uji normalitas ini digunakan untuk mengetahui kenormalan data. Rumus yang digunakan adalah uji kecocokan $\chi^{2}$ (chi kuadrat) yaitu:

$$
\chi^{2}=\Sigma \frac{\left(\mathrm{f}_{\mathrm{o}}-\mathrm{f}_{\mathrm{h}}\right)^{2}}{\mathrm{f}_{\mathrm{h}}}
$$

Keterangan :

$\chi^{2}=$ Harga chi kuadrat yang dicari

$\mathrm{f}_{\mathrm{o}}=$ Frekuensi dari hasil observasi (pengamatan)

$\mathrm{f}_{\mathrm{h}}=$ frekuensi yang diharapkan 


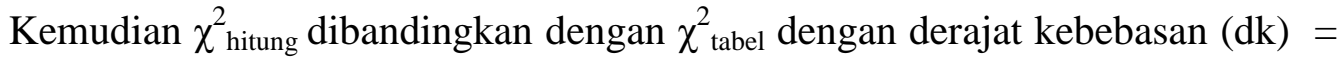
(k-1) Kriteria pengujian adalah jika $\chi_{\text {hitung }}^{2}<\chi_{\text {tabel }}^{2}$ dapat dinyatakan bahwa data berdistribusi normal.Hasil analisis uji normalitas data tes awal (pretes) dan tes akhir (postes) dapat dilihat pada tabel 7 sebagai berikut:

Tabel 7

Hasil Analisis Uji Normalitas Data Tes Menulis aksara Ulu

\begin{tabular}{llll}
\hline Variabel & $\chi_{\text {tabel }}^{2}$ & $\chi^{2}{ }_{\text {hitung }}$ & Keterangan \\
\hline Pretes & 11,07 & 5,2016 & Berdistribusi Normal \\
\hline Postes & 11,07 & 1,3542 & Berdistribusi Normal \\
\hline
\end{tabular}

Berdasarkan tabel 7 di atas, maka dapat disimpulkan bahwa memang benar data berdistribusi normal.Setelah uji normalitas diketahui, maka untuk menganalisis data hipotesis digunakan rumus uji “t”.berdasarkan perhitungan yang dilakukan diperoleh $t_{\text {hitung }}=11,61$. Hasil ini dikonsultasikan dengan $t_{\text {tabel }}$ pada taraf signifikan $1 \%$ harga yang diperoleh ialah $t_{\text {tabel }}=2,78$ sedangkan pada taraf signifikan $5 \%$ diperoleh harga $t_{\text {tabel }}=2,06$. Hal ini menunjukkan bahwa hasil perhitungan $t_{\text {hitung }}$ lebih besar dari pada nilai $\mathrm{t}_{\text {tabel }}$ baik pada taraf signifikan $1 \%$ maupun pada taraf signifikan $5 \%$. Hasil perhitungan uji perbedaan $\mathrm{t}$ dapat ditulis seperti di bawah ini.

ng $>\mathrm{t}_{\text {tabel }} 1 \%$ dan $\mathrm{t}_{\text {hitung }}>\mathrm{t}_{\text {tabel }} 5 \%$ atau $11,61>2,77$ dan $11,61>2,06$

Dengan demikian, dapat disimpulkan bahwa penerapan metode Drill secara signifikan dapat meningkatkan kemampuan menulis aksara Ulu Mahasiswa semester III Program Studi Pendidikan Bahasa dan Sastra Indonesia STKIP-PGRI Lubuklinggau.

\section{PEMBAHASAN}

Berdasarkan hasil tes awal (Pretes) dan data tes akhir (Postes), peneliti dapat menyimpulkan bahwa penerapan metode Drill secara signifikan dapat meningkatkan kemampuan menulis aksara Ulu mahasiswa Program Studi Pendidikan Bahasa dan Sastra Indonesia STKIP-PGRI Lubuklinggau. Pada hasil tes menulis aksara Ulu sebelum pembelajaran dengan metode Drill diketahui nilai terendah yang diperoleh mahasiswa adalah 32 dan nilai tertinggi yang diperoleh mahasiswa adalah 76, 
sedangkan nilai rata-ratanya adalah 58,84 sehingga kemampuan menulis aksara Ulu mahasiswa semester III Program Studi Pendidikan Bahasa dan Sastra Indonesia STKIPPGRI Lubuklinggau sebelum diberi pembelajaran dengan metode Drill masih dalam kategori Cukup. Hal ini disebabkan karena pada kegiatan pretes ini mahasiswa kurang antusias, kecilnya keinginannya dan pemahaman mahasiswa tentang materi menulis aksara Ulu. Selain itu mahasiswa belum mengenal tata cara menulis dengan menggunakan aksara Ulu sehingga mahasiswa kesulitan dalam menggunakan penanda baca dan peletakan tanda baca pada aksara ka ga nga nya.

Sedangkan hasil tes menulis aksara Ulu setelah pembelajaran menggunakan metode Drill (setelah postes) diketahui bahwa nilai terendah yang diperoleh mahasiswa adalah 68 dan nilai tertinggi yang diperoleh mahasiswa adalah 96, sedangkan nilai rataratanya adalah 84,92 (dalam kategori Sangat Baik), sehingga kemampuan menulis aksara Ulu Mahasiswa Kelas semester III Program Studi Pendidikan Bahasa dan Sastra Indonesia STKIP-PGRI Lubuklinggau menjadi lebih baik dan mengalami peningkatan sebesar 25,07 dari kegiatan awal yaitu $84,92-59,85=25,07$. Hal ini dikarenakan mahasiswa lebih berminat dan termotivasi untuk mengikuti proses belajar mengajar dengan aktif dan menyenangkan, karenapada pembelajaran ini mahasiswa diberikan kesempatan untuk berlatih satu persatu menyalin tulisan bahasa Indonesia ke dalam aksara Ulu dengan cara menulis nama masing-masing, menulis nama teman, kedua orang tua, menulis puisi dan paragraf narasi dengan menggunakan aksara Ulu.

Berdasarkan uraian nilai pretes dan postes di atas, sangat jelas terdapat peningkatan hasil belajar mahasiswa pada kegiatan pretes dan postes, diketahui nilai rata-rata mahasiswa dalam pembelajaran menulis aksara Ulu setelah menggunakan metode Drill lebih besar dibandingkan sebelum menggunakan metode Drill dan mengalami peningkatan sebesar 25,07, yaitu dari nilai rata-rata pretes sebesar 59,85 menjadi 84,92.

Sebagai pembuktian dari uraian di atas, maka dilakukan perhitungan dengan menggunakan uji " $\mathrm{t}$ ", diketahui nilai $\mathrm{t}_{\mathrm{o}}=11,61$. Kemudian nilai $\mathrm{t}_{\mathrm{o}}$ dibandingkan dengan nilai $\mathrm{t}_{\mathrm{t}}$ dengan $\mathrm{db} / \mathrm{df}=\mathrm{N}-1(26-1)=25$ pada taraf signifikansi $1 \%$ adalah 2,78 dan pada taraf signifikansi 5\% adalah 2,06. Jadi, nilai $t_{o}>t_{t}, 11,61>2,78$ dan 11,61>2,06. Hal ini berarti hipotesis yang menyatakan bahwa penerapan metode Drill secara signifikan dapat meningkatkan kemampuan menulis aksara Ulu mahasiswa semester III 
Program Studi Pendidikan Bahasa dan Sastra Indonesia STKIP-PGRI Lubuklinggau terbukti kebenarannya, hal ini sesuai dengan salah satu teori yang menjelaskan bahwa metode latihan disebut juga metode training atau drill, merupakan suatu cara mengajar yang baik untuk menanamkan dan memperoleh suatu ketangkasan, ketepatan, kesempatan, dan keterampilan serta kebiasaan-kebiasaan yang baik . Berdasarkan teori tersebut dapat diambil pengertian bahwa pelaksanaan metode driil merupakan suatu cara mengajar yang digunakan oleh guru atau dosen dengan menekankan mahasiswa untuk melaksanakan kegiatan-kegiatan latihan dengan tujuan agar mahasiswa dapat memiliki ketangkasan atau keterampilan yang lebih tinggi dari apa yang telah dipelajari Djamarah (2010).

Sebagai metode pembelajaran tentunya ada beberapa kelebihan dan kelemahan ketika guru atau dosen menerapkannya dalam kegiatan pembelajaran. Adapun kelebihan dari metode drill salah satunya adalah siswa dapat lebih mudah dalam memeperoleh kecakapan motoris, seperti menulis, melafalkan huruf, kata-kata atau kalimat, membuat alat-alat, menggunakan alat-alat (mesin permainan dan atletik), dan terampil menggunakan peralatan olahraga Djamarah (2010). Melalui metode drill mahasiswa lebih banyak mendapatkan kesempatan untuk berlatih dalam menulis Aksara Ulu. Dengan kelebihan yang telah dijelaskan tersebut maka terbukti dari penelitian yang telah dilakukan menunjukkan bahwa metode ini membantu mempermudah mahasiswa semester III pada Program Studi Pendidikan Bahasa Indonesia untuk memiliki kemampuan dalam menulis Aksara Ulu sesuai dengan indikator yang telah ditetapkan sehingga nilai rata-rata mahasiswa dalam menulis Aksara Ulu mengalami peningkatan sebesar 25,07 dari pretest ke postes yaitu dari 59,85 menjadi 84,92 (84, $92-59,85=$ $25,07)$.

\section{SIMPULAN}

Berdasarkan hasil penelitian dan pembahasan dapat disimpulkan bahwa penerapan metode Drill secara signifikan dapat meningkatkan kemampuan menulis aksara Ulu mahasiswa semester III Program Studi Pendidikan Bahasa dan Sastra Indonesia STKIP-PGRI Lubuklinggau. Hal ini dibuktikan dari hasil perhitungan uji "t", diketahui nilai $\mathrm{t}_{\mathrm{o}}=11,61$ lebih besar dari $\mathrm{t}_{\text {tabel }}$ dengan $\mathrm{db} / \mathrm{df}=26-1=25$ diperoleh 2,78 untuk taraf signifikansi $1 \%$ dan 2,06 untuk taraf signifikansi 5\% atau 11,61 > 2,78 dan 
11,61> 2,06. Besarnya peningkatan $\bar{x}$ postes $-\bar{x}$ pretes $=84,92-59.85=25,07$. Jadi besarnya peningkatan dari pretes ke postes adalah 25,07.

\section{DAFTAR PUSTAKA}

Arikunto, Suharsimi. (2010). Prosedur Penelitian. Jakarta: Rineka Cipta.

Collins, James T. (2010). Bahasa Sanskerta dan Bahasa Melayu. Jakarta: Pusbinbangsa.

Damayanti, Syamsudin. (2011). Metode Penelitian Pendidikan. Jakarta: Press.

Dewi, Rusmana. (2017). Pelestarian Aksara Ulu Banyak Kendala. Linggau Pos Online diakses 3 Desember 2017.

Djamarah, Syaiful Bahri. (2010). Strategi Belajar Mengajar. Jakarta: Rineka Cipta.

Indriaty, T. (2018). Peningkatan Kemampuan Menulis Teks Berita melalui Metode Quantum Learning dengan Media Gambar Siswa Kelas VIIIE SMP Negeri 17 Surabaya. Jurnal Kajian Bahasa, Sastra Dan Pengajaran (KIBASP), 1(2), 223236. https://doi.org/https://doi.org/10.31539/kibasp.v1i2.195

Irwanti, E. (2017). Pengembangan Bahan Ajar Menulis Puisi Bebas Kelas 8 SMP Xaverius Tugumulyo. Jurnal Kajian Bahasa, Sastra Dan Pengajaran (KIBASP), 1(1), 32 - 49. https://doi.org/https://doi.org/10.31539/kibasp.v1i1.105

Juita, R. (2018). Peningkatan Kemampuan Menulis Laporan dengan Model Pembelajaran Berbasis Portofolio. Jurnal Kajian Bahasa, Sastra Dan Pengajaran (KIBASP), 2(1), 1-10. https://doi.org/https://doi.org/10.31539/kibasp.v2i1.327

Lazuardi, D., \& Murti, S. (2018). Peningkatan Kemampuan Menulis Puisi Menggunakan Model Pembelajaran Quantum Tipe VAK (Visual, Audiovisual, Kinestetik). Jurnal Kajian Bahasa, Sastra Dan Pengajaran (KIBASP), 2(1), 8795. https://doi.org/https://doi.org/10.31539/kibasp.v2i1.408

Murniasih, S. (2017). Pengembangan Model Bahan Ajar Menulis Berita Berbasis Koran Linggau Pos Siswa Kelas 8 SMP Negeri Sumber Rejo. Jurnal Kajian Bahasa, Sastra Dan Pengajaran (KIBASP), $1(1), \quad 12 \quad$ - 31. https://doi.org/https://doi.org/10.31539/kibasp.v1i1.60

Muhtadin, E. (2017). Pengaruh Model Pembelajaran Cooperative Integrated Reading and Composition (CIRC) terhadap Kemampuan Menulis Proposal Siswa Kelas 11 MA Mazroillah Kota Lubuklinggau. Jurnal Kajian Bahasa, Sastra Dan Pengajaran (KIBASP), 1(1), https://doi.org/https://doi.org/10.31539/kibasp.v1i1.95

Noermanzah, N., Abid, S., \& Aprika, E. (2018). Pengaruh Teknik Send a Problem Terhadap Kemampuan Menulis Daftar Pustaka Siswa Kelas Xi SMA Negeri 4 
Lubuklinggau. Jurnal Kajian Bahasa, Sastra Dan Pengajaran (KIBASP), 1(2), 171-181. https://doi.org/https://doi.org/10.31539/kibasp.v1i2.273

Sagala, S. (2003). Konsep dan Makna Pembelajaran. Surabaya: Alfabeta

Sari, I. (2017). Hubungan Antara Pengetahuan Kebahasaan dengan Kemampuan Menulis Naskah Drama Berdasarkan Pengalaman Pribadi Siswa Kelas 11 SMA Negeri 1 Lubuklinggau. Jurnal Kajian Bahasa, Sastra Dan Pengajaran (KIBASP), 1(1), 119-129. https://doi.org/https://doi.org/10.31539/kibasp.v1i1.64

Sudjana, (2002). Metode Statistika. Jakarta: Pustaka Setia

Syam, Suwandi. (2015). Silabus dan Petunjuk Praktis Membaca dan Menulis Aksara Ulu (Aksara Rencong) Sumatera Selatan. Lubuklinggau: STKIP-PGRI Lubuklinggau.

Tarigan, (2008). Menulis sebagai Suatu Keteranpilan Berbahasa. Bandung: Aksara. 